\title{
Appraising the Promises of Minimum Wage in Sectoral Determination 7: Domestic Worker Sector
}

\author{
Kola O. Odeku \\ Faculty of Management and Law, School of Law, University of Limpopo, South Africa \\ Email:kooacademics@gmail.com
}

\section{Doi:10.5901/mjss.2014.v5n10p679}

\section{Abstract}

In order to strengthen the protection of domestic workers in South Africa, the government promulgated, in addition to the existing labour laws and other laws governing and regulating labour services, Sectoral Determination 7: Domestic Worker, specifically for domestic workers. This was done in view of the vulnerability of the workers and their job descriptions. This paper appraises the minimum wage aspect of the law with regard to whether it has started impacting positively on the conditions and standards of living of the domestic workers or not. It also looks at the impact of economic dynamisms such as inflation on the domestic workers' minimum wage since it was introduced and comes up with a proposal on what can be done to ensure compliance by employers.

Keywords: Domestic Workers, Minimum Wage, Non-compliance, Employers, Intimidations and Abuses.

\section{Introduction}

In South Africa, the Minister of Labour is empowered under sections 51-58 of the Basic Conditions of Employment Act, No. 75 of 1997 (BCEA), to make a Sectoral Determination for one or more sector establishing basic conditions of employment for employees in a sector and area (Moyane, et al. 2009). It was against this backdrop that the Minister of Labour, in terms of section 51(1) BCEA, made a sectoral determination known as Sectoral Determination 7: domestic worker sector, establishing conditions of employment and minimum wages for employees in the Domestic Worker Sector by virtue of government gazette, 15 August 2002 no. 23732. It was categorically stated in the law that the Sectoral Determination for domestic worker shall be binding (du Preez et al. 2010). The primary rationale behind the introduction of Sectoral Determination 7 is to protect the most vulnerable labour market sectors in South Africa such as domestic services workers and farm workers (Fourie, 2008).

Against this backdrop, the BCEA stipulates a minimum term or condition of employment (Saget, 2006). The purpose overarching promise of the BCEA "is to advance economic development and social justice by fulfilling the primary objects of this Act which are-

a) to give effect to and regulate the right to fair labour practices conferred by section 23(1) of the Constitution-

i) by establishing and enforcing basic conditions of employment; and

ii) by regulating the variation of basic of basic conditions of employment;

b) to give effect to obligations incurred by the Republic as a member state of the International Labour Organisation."

It is pertinent to point out that while other conditions of employments are well outlined and articulated in the BCEA, the minimum remuneration which an employer must pay is apparently omitted in the BCEA (Lewis, 2001). As a result of this, it is the prerogative of the employer and employee or representative trade union to negotiate the minimum wage for which the employee will work (Budeli, 2010).

However, with regard to the sectors that employ vulnerable workers such as domestic workers and farm workers, the Minister has the responsibility to regulate the conditions by making a sectoral determination that will specifically prescribes the minimum conditions of employment including remuneration (Matjeke, 2010). The domestic sector is considered to be poor bargaining power and not well unionised like other vibrant advantaged sectors, hence the intervention of the Minister becomes very significant, otherwise the workers would be disadvantaged and exploited (Grant, 1997). Issuing sectorial determination fills the remuneration and wage gaps by prescribing the minimum remuneration and the periodic adjustment of such minimum rates of remuneration (Bhorat et al. 2013).

The focus of this paper is to appraise the dynamism of the minimum wage for workers in the domestic sector and 
how employers are ensuring that they actually comply with the mandate of the Act. Minimum wage is defined as the minimum amount payable as compensation by an employer to an employee for rendering labour services (Stone, 2006).

Through government intervention, minimum wages are usually prescribed by contract or legislation (Chen et al. 2002). To this end, it will be a violation of the law to pay an employee less than the minimum wage and there are consequences for non-compliance (Rani et al. 2013). The overarching importance of setting or prescribing minimum wage is mostly to protect employees, particularly vulnerable and non-unionised employees from exploitation by the employers (Misra, 2008). As a socio-economic right, it guarantees employees basic standard of living whereby they can access and afford basic necessities of life (Sheahen, 2012).

It is also a right that has found expression in both national and international instruments. Against this backdrop, Sheahen ( 2012) contends that "there is a moral obligation to provide every man, woman, and child with a decent level of living. Your right to be-Your right to simple existence-is not something for others to grant or withhold as an economic carrot, or to give as a gift. It is a universal right. Some call it "Social Security for everyone."

Minimum wage is also a strong tool being used to alleviate poverty, close the wealth gap, and provide economic security to everyone by giving all citizens a modest yet unconditional income that will take care of them and their households (Wright, 2000).

Minimum wage varies from one country to another and sometimes between states or provinces depending on the level of economic activities and cost of living (Eyraud and Saget, 2005).

One of the prominent promises inherent in the Act is that it will bring to the fore the interesting debate on the status of domestic workers in the workplace and society (Magwaza, 2008). The Act outlines basic conditions of employment of the workers in this sector and for the first time succinctly enshrined the job descriptions of an employee performing the job of domestic work. With regard to the employment of those who are covered and recognised in the Act, the Act provides that

1) The determination applies to the employment of all domestic workers in the Republic of South Africa including domestic workers -

a) employed or supplied by employment services;

b) employed as independent contractors.

2) This determination does not apply to domestic workers -

a) employed on farms on which employees performing agricultural work are employed;

b) covered by another sectoral determination in terms of the Basic Conditions of Employment Act; or

c) covered by an agreement of a bargaining council in terms of the Labour Relations Act, 1995.

3) Only c lauses 2 and 3 setting minimum wages apply to domestic workers who work less than 24 hours per month for an employer.

4) The provisions of the Basic Conditions of Employment Act apply to all domestic workers covered by this determination and their employers in respect of any matter not regulated by this sectoral determination."

Against the backdrop of above recognition, those who are in the sectors mentioned above have ample protection of the law, and the employers are by this determination estopped from arbitrarily violating the labour rights of these vulnerable persons. More importantly, the protection also duly recognises them as employees under the law which leveraged their status and as such they are entitled to various labour redresses as enshrined in the law. Therefore, the essence of the law therefore is to protect these vulnerable workers in order for it to remain relevant (Smit and Fourie, 2010). Reinforcing this Ramirez-Machado (2003) notes that these protective mechanisms become inevitable because "domestic workers are vulnerable workers and are exposed to many abuses such as arbitrary changes of work contracts, pay cuts or even non-payment of salaries are facilitated by the irregular nature of the employment relationship." In general terms, domestic work is a low paying activity and most times, the salary is often far below the minimum wage prescribed by the law (Ramirez-Machado, 2003).

\section{Literature Review}

Domestic work is not only widespread but thriving and increasing at an astronomical rate worldwide (Gregson and Lowe, 2005). In South Africa for an example, the sector employs more than one million people and it is one of the largest sources of employment for black women particularly the uneducated and the poor (du Preez et al. 2010). Also, apart from being vulnerable, they are the most neglected sets of people in the employment relationships ( Kalleberg, 2009). Against the backdrop of this deliberate neglect, Christel (2009) writes about the rapid intervention that was put in place in order to address the apparent injustices being perpetrated by the employers in this sector and says "the South African domestic worker sector is recognised as one of the most neglected sectors of the country's labour force. Scholarly and societal 
calls for legislative reform within this sector culminated in the proclamation of Sectoral Determination 7: Domestic Worker Sector, which stipulates the minimum employment conditions for this sector as from 1 September 2002."

Issues relating to wages are always problematic and as such, there have been numerous government interventions in order to fix the wage and protect the workers from intimidation and harassment by the employers (D'Souza, 2010). Commenting on the precarious and vulnerable situations of domestic workers, Fourie (2008) writes "these workers are often paid for results rather than time. Their vulnerability is linked in many instances to the absence of an employment relationship or the existence of a flimsy one. Most of these workers are unskilled or work in sectors with limited trade union organisation and limited coverage by collective bargaining, leaving them vulnerable to exploitation. They should, in theory, have the protection of current South African labour legislation, but in practice the unusual circumstances of their employment render the enforcement of their rights problematic. The majority of non-standard workers in South Africa are those previously disadvantaged by the apartheid regime, compromising women and unskilled black workers. The exclusion of these workers from labour legislation can be seen as discrimination, which is prohibited by almost all labour legislation in South Africa. This contribution illustrates how the concept of indirect discrimination can be an important tool used to provide labour protection to these workers."

Similarly, the study conducted by Benassi (2011:2) revealed that "minimum wage is one of the most used instruments for affecting the wage distribution on the labour market. In fact, minimum wage is provided by law in $90 \%$ of the world's countries; however, its implementation varies highly in both approach and effectiveness across countries. Because of its potential redistributive effect, setting a minimum wage as a matter of policy is a contentious political issue and object of controversies among the government, workers' organizations and employers. Because of these controversies, there still lacks a coherent debate about effective minimum wage implementation strategies."

While the issues of wages are important, it should not be the only focus in this sector. Therefore, it is important to point out that the wage should be a living wage and negotiation around it should take into consideration social and political bargaining in favour of legislation to promote labour and social protection (Smit and Fourie, 2010). Interestingly, in South Africa, the issues surrounding minimum wages have been successfully legislatively dealt with as aptly put by Hertz (2005) thus "minimum wages have been in place for South Africa's one million domestic service workers since November of 2002. Using data from seven waves of the Labour Force Survey, this paper documents that the real wages, average monthly earnings, and total earnings of all employed domestic workers have risen since the regulations came into effect, while hours of work per week and employment have fallen. Each of these outcomes can be linked econometrically to the arrival of the minimum wage regulations. The overall estimated elasticities suggest that the regulations should have reduced poverty somewhat for domestic workers, although this last conclusion is the least robust" Hertz (2005) goes further to point out that "in November of 2002, a schedule of minimum wages including timeand-a-half provisions for overtime work went into effect. The minimal were set above the median hourly wages that prevailed at the time, and so constitute a major intervention in South Africa's lowest-wage labor market. (The minima were increased in November of 2003 and again in November of 2004.) As of May 2003, employers were also required to register any domestic workers whom they employed for more than 24 hours a month with the Unemployment Insurance Fund (UIF) and to withhold UIF contributions from their paychecks. At that point employed and contributing domestic workers began to earn credits towards future potential UIF benefits, at a rate one day's benefit for every six."

\section{The Significance of Protection}

To a large extent, the society has these misgivings and derogative tendencies toward the work of domestic workers (Gast and Patmore, 2012). It is therefore not surprising that a lot of people perceive the job as typical, non-standard, or even marginal vocation reserved for drop outs and not-doing well (Fredman, 2005). There are many terms being used to describe these workers and include, amongst others, part-time work, contract work, self-employment, temporary, fixedterm, seasonal, casual, piece-rate work, employees supplied by employment agencies, home workers and those employed in the informal economy (Fourie, 2008). In South Africa, "there are approximately one million, mainly black women, who are domestic workers in South Africa. The Basic Conditions of Employment Act (BCEA) is the overarching piece of legislation that regulates their wages and working conditions in addition to, broadly speaking, all unorganised workers in South Africa" ( Motala, 2010). The number continues to increase on a daily basis as it is one of the informal jobs available that provides means of sustenance for the workers and their family; sometimes accommodation is also provided for them in the employer's house (Anderson, 2000).

Due to the nature of their vulnerability, workers in this sector are at times ready to do the job and get paid based on results rather than time (Fourie, 2008). Pursuant to this, they do not have the normal closing hours and can only rest or sleep when their allocated task which may require 20 hours to carry out is completed (Anderson, 2000). Fourie (2008) 
points out that "their vulnerability is linked in many instances to the absence of an employment relationship or the existence of a flimsy one. Most of these workers are unskilled or work in sectors with limited trade union organisation and limited coverage by collective bargaining, leaving them vulnerable to exploitation."

These vulnerable workers should have the protection of the current South African labour legislation and laws (Fourie, 2008). Although, in practice, the unusual circumstances of their employment render the enforcement of their rights problematic because they are mostly invisible and the level of abuse and violation are kept secrets to themselves for fear of reprisals by the employers. ( Parreñas, 2001). Therefore, protection is important to them, even more than workers in other sectors. As part of ensuring that the law is complied with, an employer hiring a domestic worker needs to educate and sensitise the worker on the issue of the rights to fair labour practice and in particularly payment of minimum wage as set out in the pieces of legislation (Fourie, 2008).

\section{Implementing Minimum Wage and The Issue of Cost of Living}

Paying wages for services rendered by domestic workers are not enough, there is need to pay a living wage as prescribed by the law. Living wages here presupposes that domestic workers' salaries should be reviewed on a yearly basis based on the level of inflation just like wages of workers in other sectors. It is pertinent to point out why the conditions of employment of domestic workers have been very poor and deplorable in South Africa in the past and in this regard, du Preez et al. (2010) writes that "historically, the impact of apartheid has been to skew the analysis of employment relationships in domestic workspaces in South Africa so that the power asymmetry and exploitation that so characterise these relationships have been labelled an artefact of the racist apartheid regime and its legislation." But the situation has now changed particularly with regard to wages with the promulgation of the sectoral determination which categorically prescribed living wages and in addition also prescribed the annual increases and revised wages, taking into consideration the cost of living. This is against the backdrop that domestic workers spend a huge part of their income on subsistence like food. Food prices have risen sharply in recent years and continue to rise and this is consuming a large portion of poor workers' earnings (Motala, 2010).

In a bid to seek to diversifying and strengthening minimum wage implementation, the study conducted by Benassi (2011:ii) came up with a workable five strategies s follows "first, persuasion strategies should be used to build public support for the minimum wage and encourage employers to comply voluntarily. Second, capacity building measures such as information sessions and training seminars should be undertaken so that employers and workers are informed about the minimum wage and so that employers know how to implement it in their firms. Third, the monitoring system should allow the detection of non-compliance. Labour inspections should be reinforced and carried out, especially in the sectors at risk; complaint procedures should be made more accessible and safer to workers and their representatives. Fourth, workers should be empowered to enforce their wage rights not just through individual complaints, but also through collective action, as workers fear retaliation when they are required to undertake individual action. For instance, unions should be given access to information on workers' wages, the opportunity to organize workers and the power to act on workers' behalf. Finally, sanctions should be structured such that they constitute an actual deterrent to non-compliance. This means that the cost of sanctions should be higher than the benefit of workers' underpayment. Moreover, the application of sanctions should be sure and incremental."

These strategies are worth emulating and their implementation should be encouraged in South Africa. However, for this to materialise, it requires the support of all stake and role players. To this end, government is enjoined to provide leadership through a genuine political will by emulating these strategies in conjunction with existing pieces of legislation. This will definitely strengthen compliance and enforcement.

\section{Hidden Transactions}

The law is very clear on the minimum wage payable to workers including domestic workers. This is realisable through the BCEA which makes provision for sectoral determinations. The provisions that are significant to domestic workers such as review and increment of minimum wage yearly came into effect in 2002 and still exist till date. More importantly, it is pertinent to point out that whilst all the conditions have remained the same, since December 2010, the minimum wage for full-time domestic workers has been R1442.86 or R1191.78 per month depending on the geographical area in which the worker works (Motala, 2010). In spite of this, majority of employers are failing to comply with the law, sometimes pretending ignorant of the law with the aim of perpetrating exploitations of vulnerable domestic workers.

The study conducted by Ramirez-Machado (2003) revealed that "domestic worker is a very heterogeneous category, difficult to define and therefore to protect... its weakness is even more reinforced by a very specific 
characteristic of this category of worker: its invisibility. Their invisibility derives primarily from the characteristics of the workplace itself- the private household. Labour inspection and enforcement of legislation are difficult in private households and, even more so, the organization of a collective action. In the case of clandestine situations, which can occur more easily in this type of workplace, workers are even more vulnerable. Their invisibility is reinforced by the inaccuracy and/or unavailability of data on domestic workers, often linked to reliance on domestic workers being registered for information gathering. Knowing that domestic work is mainly performed by women, that the use of child domestic labour is widespread and that, in some countries, a large part of the domestic labour force is made up of migrant workers, we cannot measure its real extent."

Against the backdrop of the above vulnerability well expressed and presented in the study of Ramirez-Machado (2003), a lot needs to be done by the enforcers of the labour regulations protecting vulnerable domestic workers. Writing and promulgating laws are not enough, active and proactive steps and measures should be put in place to implement and enforce the contents of the laws. This point is made against the backdrop that a lot of hidden transactions inform of connivances, intimidations, harassments, threats of dismissals and a whole lots of abusive tendencies are being perpetrated and ongoing against domestic workers at their workplaces on a daily basis.

A lot of domestic workers are not enjoying the promises of sectoral determination 7, in particular wages and increase in wages, as they are still being paid below the prescribed statutory wages but they don't complain or lodge reports to the appropriate institutions for protection because they have been psychologically supressed and are afraid to lodge complaints against the employers. The promises in the law will therefore become meaningful if there is stringent monitoring and control and severe sanctions for violation.

Increase in wages and remunerations of domestic workers will only be meaningful if the law is fully implemented and meticulously followed by close monitoring and achieve desire result as argued by Dinkelman and Ranchhod (2012) that "what happens when a previously uncovered labour market is regulated? We exploit the introduction of a minimum wage in South Africa and variation in the intensity of this law to identify increases in wages for domestic workers and no statistically significant effects on employment on the intensive or extensive margins. These large, partial responses to the law are somewhat surprising, given the lack of monitoring and enforcement in this informal sector. We interpret these changes as evidence that strong external sanctions are not necessary for new labour legislation to have a significant impact on informal sectors of developing countries, at least in the short-run."

However, it is pertinent to point out that while some employers are deliberately depriving domestic workers basic conditions of employments, some employers are ignorant of the laws or policy regulating the sector hence unable to comply with the law. Against this background, the study conducted by Christel (2009) revealed that "employers have limited awareness and that it is difficult to make a general pronouncement regarding compliance levels. An exploration of the link between awareness of employment standards and actions showed that awareness cannot be taken for granted and does not guarantee compliance. Compliance, however, gives awareness."

\section{Conclusion}

Minimum wage is a product of law and as such it must be implemented by employers. Usually, it is fixed for those who perform vulnerable works and do not know their right from wrong. It is incumbent on employers to apply their minds to the issues surrounding payment of minimum wages and implement them. The plea of ignorance of the law will not avail an erring employer. Government is enjoined to continue to play the monitoring and enforcement roles to strengthen compliance. Minimum wage allows for economic inclusion and social cohesion. Therefore, living wage that will improve the standard of living of the workers is a recipe for political stability and peace. To assure peace and tranquillity which will lead to minimal wage disputes and labour unrest, continuous and periodic review of the minimum wage should be made by the government taking into account the prevailing economic situation and the level of inflation in the society.

\section{Recommendations}

It is imperative to ensure that institutions that have been put in place to serve as oversights are doing the right things by exposing employers who are undermining the law on minimum wage by ways of refusal to pay, intimidating employees, engaging in hidden transactions where employees are coerced to accept payment lower than the minimum wage and so on. Sanction for non-compliance should be severe and punitive in order to serve as deterrent. Employees should be encouraged to join trade unions without any fear of reprisals, threat of dismissals and so on. More importantly, considering that it is the employer that have direct dealings with the employees, it will be morally and legally imperative for them to do the right thing by informing the employees about their right to minimum wage subject to periodical reviews. 
By so doing, employers will be part of the solution of alleviating poverty and raising standard of living of these vulnerable workers.

\section{References}

Anderson B 2000. Doing the dirty work?: the global politics of domestic labour. London, UK: Zed Books, Ltd.

Benassi C 2011. The implementation of minimum wage: Challenges and creative solutions. From.http://olumn.global-labouruniversity.org/fileadmin/glu_working_papers/glu_wp_no.12.pdf. (Retrieved on 4 October, 2013).

Bhorat $\mathrm{H}$, Kanbur R, Mayet N 2013. The impact of sectoral minimum wage laws on employment, wages, and hours of work in South Africa. IZA Journal of Labor \& Development, 2(1):1-27.

Budeli M 2010. Labour law. M McGregor, - Annual Survey of South African Law, 2010. Annual Survey of South African Law. From http://reference.sabinet.co.za/sa_epublication_article/ju_assal_2010_a21. (Retrieved on 19 December, 2013).

Chen MA, Jhabvala $R$, Lund $F$ 2002. Supporting workers in the informal economy: a policy framework. from https://wiego.org/sites/wiego.org/files/publications/files/ expired\&ncoap=1. (Retrieved on 16 June, 2012).

Christel M 2009. Labour Legislation in Emfuleni's domestic work sector:awareness and compliance. South African Journal of Labour Relations, 33(1):65-85.

D'Souza A 2010. Moving towards decent work for domestic workers: An overview of the ILO's. From work.http://courses.ttcilo.org/A906119/documentation/ilo-studies-papers/moving\%20towards\%20dwdw\%20overview\%20of\% 20ilos\%20work.pdf. (Retrieved on 18 September, 2013).

Du Preez J, Beswick C, Whittaker L, Dickinson D 2010. The employment relationship in the domestic workspace in South Africa: beyond the apartheid legacy. Social Dynamics: A journal of African studies. 36(2): 395-409.

Eyraud F Saget C 2005. The fundamentals of minimum wage fixing. Geneva, Switzerland: International Labour Organisation Publication.

Fourie ES 2008. Non-standard workers: the South African context, international law and regulation by the European Union. From http://www.scielo.org.za/scielo.php?pid=S1727-37812008000400005\&script=sci_arttext. (Retrieved on 15 September, 2013).

Fredman S 2005. Control Over Time and Work Life Balance: Comaprative/Theoretical Perspective. From http://www.labour.gc.ca/eng/ standards_equity/index.shtml. (Retrieved on 12 November, 2013).

Gast L, Patmore A 2012. Mastering Approaches to Diversity in Social Work. London UK:Jessika Kingsley Publishers.

Grant A 1997. Domestic workers employees or servants? Agenda: Empowering women for gender equity. The Labour Market, 13(35):61-65.

Gregson N, Lowe M 2005. Servicing the middle classes: class, gender and waged domestic work in contemporary Britain, From http://books.google.co.za/books?hl=en\&lr=\&id=lpwjagaaqbaj\&oi=fnd\&pg=pp1\&dq. (Retrieved on 11 July, 2013).

Hertz T 2005. The effect of minimum wages on the employment and earnings of South Africa's domestic service workers. aladinrc.wrlc.org.The Effect of Minimum Wages on the Employment and Earnings of South Africa's Domestic Service Workers. From http://aladinrc.wrlc.org/handle/1961/4960. (Retrieved on 2 June, 2013).

Kalleberg AL 2009. Precarious Work, Insecure Workers: Employment Relations in Transition. American Sociological Review, 74(1): 122.

Lewis JD 2001. Policies to promote growth and employment in South Africa. From http://www.tips.org.za/files/ Policies_to_Promote_Growth_and_Employment_in_South_Africa.pdf. (Retrieved on 9 June, 2013).

Magwaza T 2008. Agenda: Empowering women for gender equity. Engendering National \& Global Economic Policies, 22(78):79-92.

Matjeke MA 2010. The impact of minimum wages on the market for domestic workers in South Africa. From ujdigispace.uj.ac.za.https://ujdigispace.uj.ac.za/handle/10210/3419. (Retrieved on 6 January, 2014).

Misra N 2008. Strategic Unionism: the political role of the Congress of South African Trade Unions (COSATU) in South Africa and what it means for black workers. From dspace.mit.edu. http://dspace.mit.edu/handle/1721.1/46624. (Retrieved on 27 August, 2013).

Motala M 2010. Domestic Workers in South Africa: It's Modern Day Slavery. From http://www.sacsis.org.za/site/article/473. (Retrieved on 22 June, 2013).

Moyane K, Strydom EML, Young KL, Jordaan B 2009. Understanding the Basic Conditions of Employment Act. Cape Town, South Africa: Juta \& Co, Ltd.

Parreñas RS 2001. Servants of globalization: Women, migration and domestic work. California, USA: Stanford University Press.

Ramirez-Machado JM 2003. Domestic work, conditions of work and employment: A legal perspective. From http://www.ilo.int /wcmsp5/groups/public/---ed_protect/---protrav/---travail/documents/publication/wcms_travail_pub_7.pdf. (Retrieved on 10 July, 2013).

Rani U, Belser P, Oelz M, Ranjbar R 2013. Minimum wage coverage and compliance in developing countries. International Labour Review. 152(3-4): 381-410.

Saget C 2006. Wage fixing in the informal economy: Evidence from Brazil, India, Indonesia and South Africa. From http://www.ilo.int/wcmsp5/groups/public/---ed_protect/---protrav/---travail/documents/publication/wcms_travail_pub_16.pdf. (Retrieved on 24 July, 2013).

Sheahen A 2012. Basic income guarantee: Your right to economic security. from http://books.google.co.za/ books?hl=en\&lr=\&id=sbl5uncvfkec\&oi=fnd\&pg=pr9\&dqwif39y5fu2\&sig=xcdhwptm|3eltn4uy2fjxo9v06o\#v=onepage\&q\&f=false.

(Retrieved on 20 January, 2014).

Smit N, Fourie E 2010. Extending Protection to Atypical Workers, Including Workers in the Informal Economy, in Developing Countries'. 
International Journal of Comparative Labour Law and Industrial Relations, 26(1): 43-60.

Smit N, Fourie E 2010. Extending protection to atypical workers, including workers in the informal economy in developing countries. International Journal of Comparative Labour Law and Industrial Relations, Issue 26(1): 43-60.

Stone KVW 2006. Legal Protections for Atypical Employees: Employment Law for Workers without Workplaces and Employees without Employers. Berkeley Journal of Employment \& Labor Law, 27(2):251-286.

Wright EO 2000. Reducing Income and Wealth Inequality: Real Utopian Proposals. Contemporary Sociology, 29(1): 143-156. 